\title{
DOUBLE SHEAR DESIGN TO REDUCED STAMPING FORCE
}

\author{
Rudi Kurniawan Arief \\ Departemen Teknik Mesin, Fakultas Teknik, Universitas Muhammadiyah Sumatera Barat \\ Email: rudikarief@umsb.ac.id
}

\begin{abstract}
Ideally processing of part using stamping machine using only $70-80 \%$ of available force to keep machine in good shape for a long periods. But in some certain case the force may equal to or exceed the available maximum force so the company must sent the process to another outsource company. A case found in a metal stamping company where a final product consist of 3 parts to assembly with one part exceeded the force of available machine. This part can only process in a 1000 tons machine while this company only have 2 of this machine with full workload. Sending this parts outsource will induce delivery problems because other parts are processed, assembled and paint inhouse, this also need additional transportation cost and extra supervision to ensure the quality and delivery schedule. The only exit action of this problem is by reducing the force tonnage. This paper using punch inclining method to reduce the force. The incline punch will distributed the force along the inclined surface that reduce stamping force as well. Inclined surface of punch also cause another major problems that the product becoming curved after process. This problems solved with additional flattening process that add more process cost but better than to outsource the process. Chisel type of inclining punch tip was choosen to avoid worst deformation of product. This paper will give the scientific recomendation to the company.
\end{abstract}

Keywords : Metal Stamping, Force Reduction, Inclining Punch, Shearing process, Cutting Force.

\section{PREFACE}

Ideally processing of part using stamping machine using only 70-80\% of available force to keep machine in good shape for a long periods. But in some certain case the force may equal to or exceed the available maximum force so the company must sent the process to another outsource company. A case found in a metal stamping company where a final product consist of 3 parts to assembly with one part exceeded the force of available machine. This part can only process in a 1000 tons machine while this company only have 2 units of this machine with full workload. Other machine with 500 tons force available 4 units with medium load. To process this parts in 500 Tons machine will gain effeciencies in time production cost. Sending this parts outsource will induce delivery problems because other parts are processed, assembled and paint inhouse, this also need additional transportation cost and extra supervision to ensure the quality and delivery schedule.

The only exit action of this problem is by reducing the force tonnage. Punch or die inclining method is use to reduce the force. The incline punch will distributed the force along the inclined surface that reduce stamping force as well. The company already incline the punch slightly but not reducing a lot of force. View years ago, in the late 2005, Mr. Konishi, a senior engineer from head office Japan, give his advice to use the combination of flat and double shear type, but this advice never be applied until today. This paper will calculate theoritically the design that advised by the advisor to give the scientific recomendation to the company. 


\section{LITERATURE REVIEW}

Force Reduction Methods. Sometime we face the problem of excessive stamping force that unaffordable by available press machine. Several methods can be use to reduce the stamping force such as inclined punch and staggered punch. Staggered punch usually applied for piercing process with multi punch, the punches then staggered or set in several different height to be able to cut stimultaneously one after another. For blanking process with bigger size usually inclined punch is used. This inclined punch surface also known as shear, because it works as the shearing process like a scissor. Inclined surface may reduce cutting force up to $25 \%$ [3].

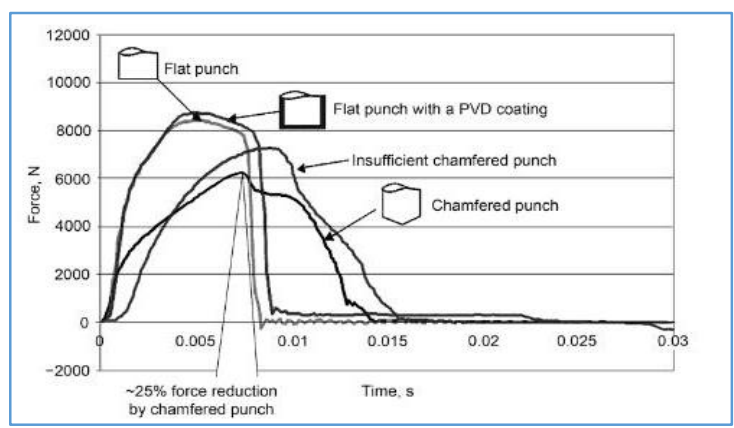

Figure 1. Force reduction with different punch geometries [3]

Maximum stamping force can be reduced because punch pushing small amount of materials (b) step by step instead of pushing all materials together (a) as shown in figure 1 below.

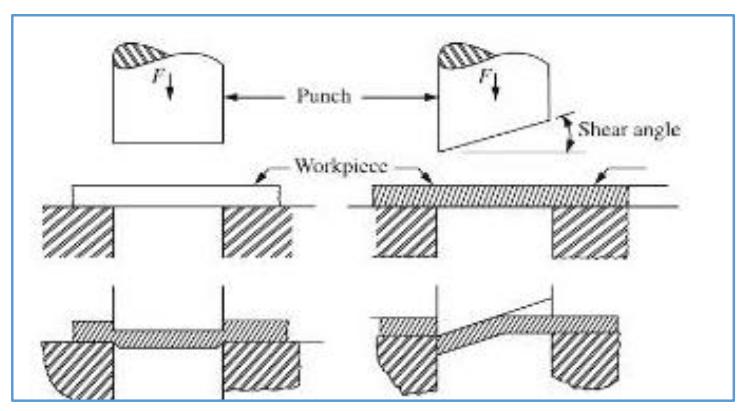

(a)

(b)

Figure 2. Material pushing in stamping process [2]

Many type of inclined surface also applicable for punch surface with some advantages and disadvantages, the slug or blanking part might be deformed into the shapes of punch.

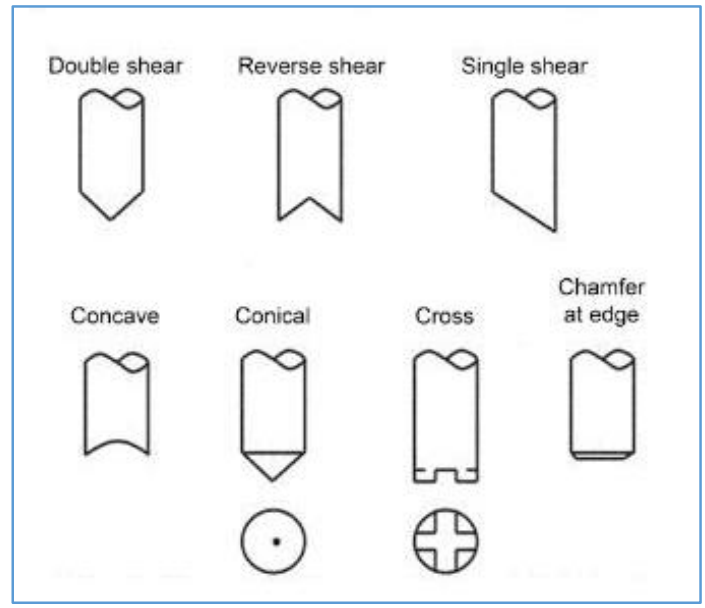

Figure 3. Punch Inclined Shape [3]

As the punch shape inclined, slug surface might be deformed according to inclined types. Figures below shown the slugs appearance after processed.

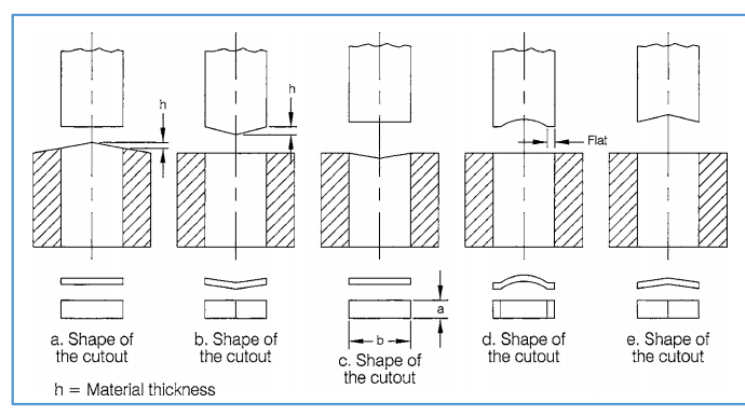

Figure 4. Slug deformation apearance [1]

As the cut-out part will be resemble the shape of it's punch, so it is advisable to use inclined punch for piercing process and inclined dies for blanking process. Figure 4 above explained that inclined dies surface will produced flat and better slug that suitable for blanking process to avoid deformation. But machinery and maintenance difficulties will be issues to be considered. The angle of inclined punch depend on material thickness [4] :

1. For $\mathrm{t} \leq 3 \mathrm{~mm}=\mathrm{h} \leq 2 \mathrm{t}$ and $\alpha \leq 5^{\circ}$

2. For $\mathrm{t}>3 \mathrm{~mm}=\mathrm{h}=\mathrm{t}$ and $\alpha \leq 8^{\circ}$

Where : $H$ is height of inclined surface, $t$ is material thickness. 


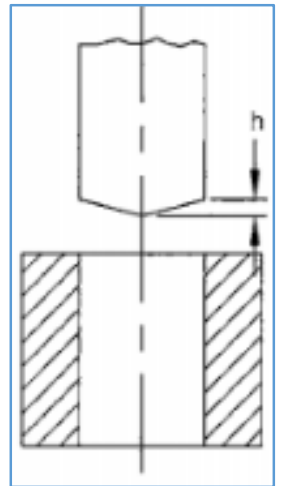

Figure 5. Inclined Punch

The higher shear angle applied on the punch, bigger possibility for workpiece to be deformed. Depend on tolerances and process planning, the deformation may acceptable if under tolerance specification, otherwise additional process will be required or deformation can be fixed in next step of the process.

Stamping force formula. Stamping force must be determined at the beginning to decide with press machine to use. This stamping force must be slightly lower than maximum press machine capacity for maintenance reason but somehow the stamping force were slightly higher. Under this situation inclined surfaced is applied.

Stamping force calculated by considering the length of cutting edge, material thickness and shear strength of material as formulated below:

$$
\begin{aligned}
& \mathrm{P}=\text { L.t.Sc } \\
& \begin{aligned}
\text { Where } \mathrm{P}=\text { Cutting Force }(\mathrm{KgF}) \\
\mathrm{t}=\text { Material Thickness } \\
\mathrm{L}=\text { Length of Cut } \\
\mathrm{Sc}=\text { Maximum CuttingStrength (See } \\
\quad \text { table } 1) \\
\mathrm{Sy}=\text { Yield Strength }
\end{aligned}
\end{aligned}
$$

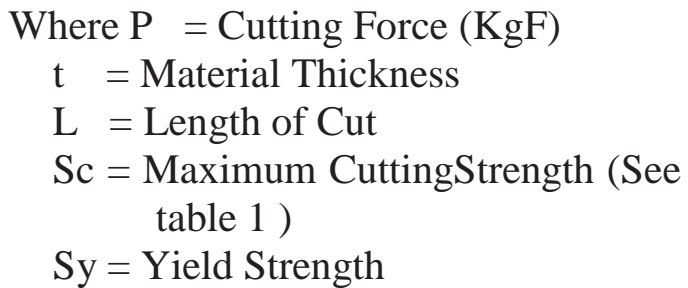

Table 1. Material Maximum Cutting Strength $(\mathrm{Sc})$

\begin{tabular}{|lc}
\hline \multicolumn{1}{c}{ Material } & Maximum cutting strength, $S_{c}$ \\
\hline Alumunum, soft & $(.75-.90) S_{y}$ \\
Aluminum, hard & $(.60-.65) S_{y}$ \\
Steel & $(.75-.90) S_{y}$ \\
Stainless steel & $(.68-.72) S_{y}$ \\
Titanium alloys & $(.65-.70) S_{y}$ \\
\hline \multicolumn{2}{|c}{ Note: Where $S_{y}$ is the yield strength of the material. } \\
\hline
\end{tabular}

Stamping force for inclined punch or dies operation is estimated as below :

$$
\mathrm{P}=0,7 \text {. k.L.t.UTS }
$$

Where :

$$
\begin{aligned}
& \mathrm{P}=\text { Cutting Force }(\mathrm{KgF}) \\
& \mathrm{k}=\text { Constant value }: 0,4 \\
& : 0,2 \\
& \mathrm{t}=\text { Material thickness } \\
& \text { UTS }=\text { Ultimate Tensile } \\
& \mathrm{SC}=(0,75-0,9) . \mathrm{Sy} \\
& \mathrm{SC}=0,8 . \mathrm{Sy} \\
& \mathrm{SC}=0,8.240=192
\end{aligned}
$$$$
\mathrm{k}=\text { Constant value : } 0,4 \sim 0,6 \text { for } \mathrm{h}=\mathrm{t}
$$$$
\text { : } 0,2 \sim 0,4 \text { for } h=2 t
$$$$
\text { UTS = Ultimate Tensile Strength }
$$

\section{DESIGN IMPLEMENTATION}

The Case. The case was taken from Japanese owned metal stamping company located in Bekasi area, Indonesia. The assembly part consist of 4 stamping parts with welded assembly. Biggest stamping part made of $6 \mathrm{~mm}$ thickness SPCC material is planned to have 4 stamping process. The process are : Blanking, $1^{\text {st }}$ piercing, Ubending and $2^{\text {nd }}$ pierce.

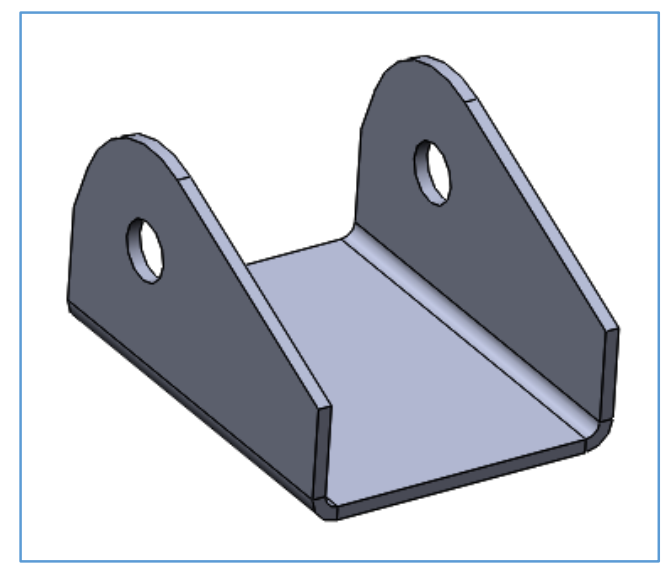

Figure 6. Finished part 
The blanking process required force as estimated below:

Where $\mathrm{t}=6 \mathrm{~mm}$

$$
\begin{aligned}
& \mathrm{L}=703,4 \mathrm{~mm} \\
& \mathrm{Sy}=240(\text { for } \mathrm{SPCC}) \\
& \begin{aligned}
\mathrm{Sc} & =0,8 \cdot \mathrm{Sy} \\
& =0,8 \cdot 240 \\
& =192
\end{aligned} \\
& \mathrm{P}=703,4 \times 6 \times 192 \\
& =810.320 \mathrm{KgF} \approx 811 \text { Tons }
\end{aligned}
$$

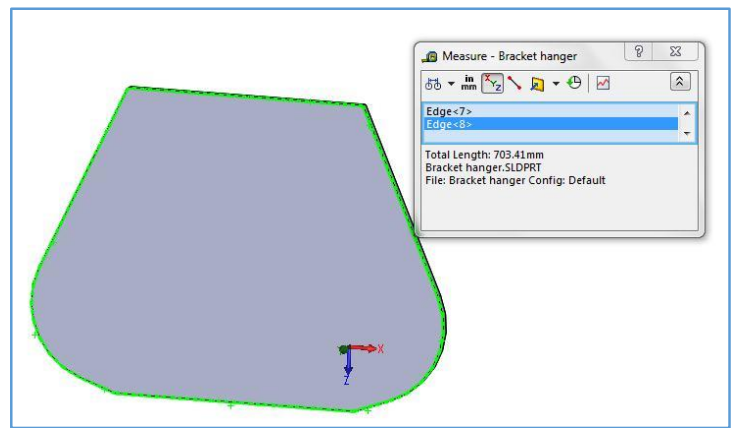

Figure 7. Total perimeter length of blank

From equation above means that this workpiece should be process in 1000 Tons stamping machine. Due to high utilities of 1000 Tons machine, the company tries to reduce the force by inclining the punch surface method. To process in other company is not an option because will require higher cost for transportation and stamping fee. The target is to reduce the force to 450 Tons so this can be process with 500 Tons stamping machine.

Case Countermeasures. Inclined surface is chosen as force reducing method because this method may reduce the cutting force up to $50 \%$ and shear process produce lower shock and sound. With $6 \mathrm{~mm}$ of material thickness the maximum inclined height should be equal to material thickness with inclined degree less than $8^{\circ}$.

Inclined punch with double shear method was chosen rather than inclined dies, the product will be deformed and buckling but the manufacturing and maintenance cost were much lower. Since the cut-out parts will deform to shape of punch double shear punch then will produce NG blank parts. In the late 2005, Mr. Konishi, a senior engineer from head office Japan, give his advice to use the combination of flat and double shear type (Figure 7). This advice considering how to gain high force reduction but still keeping the good surface of the middle surface.

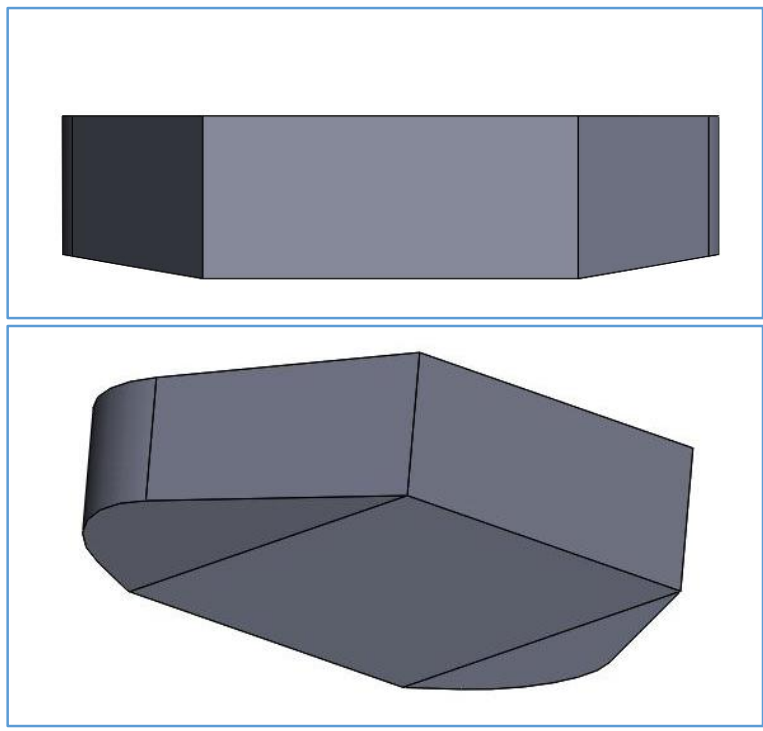

Figure 8. Inclined shape of punch

With this type cutting force and deformation of material can be reduce. Flat surface will act as conventional stamping and then continue by shearing to the rest of it. Double shear punch is suitable for piercing process because the scraps will deform to "V" shape and disposable while for blanking it will deformed the workpiece.

Stamping Force Calculation. The punch divided into 3 parts (Fig 3.3) Flat surface punch taken along $140 \mathrm{~mm}$, this is the position of flat surface of part after bending. With this type, blanking process is divide into to stages, first stage is the flat surface punching then follow with shear punching.

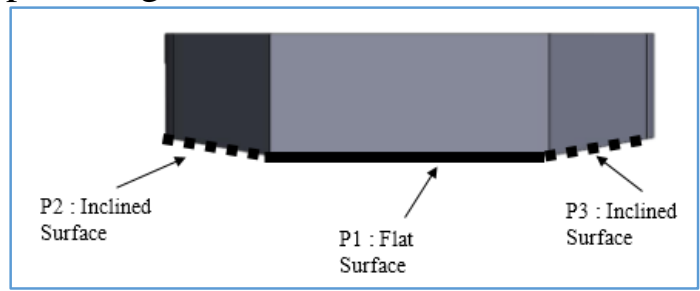

Figure 9. Design of punch shapes 
Cutting force will be $\mathrm{P} 1$ and $\mathrm{P} 2+\mathrm{P} 3$

Cutting force at P1 :

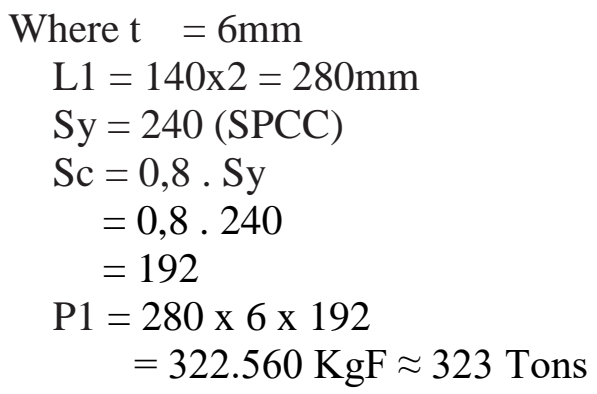

Cutting force at inclined punch (P2 \& P3) is estimated as below :

$$
\mathrm{P} 2=\mathrm{P} 3
$$

$$
\begin{aligned}
& \text { Where: } \mathrm{h}=\mathrm{t}=6 \mathrm{~mm} \\
& \mathrm{k}=0,5 \\
& \mathrm{t}=6 \mathrm{~mm}(\mathrm{SPCC}) \\
& \mathrm{L} 2=213 \\
& \mathrm{UTS}=270(\mathrm{JIS} \mathrm{G} 3141) \\
& \mathrm{P} 2=0,7 \cdot 0,5.106,6.6 .270 \\
& \\
& \mathrm{P} 2=120 \cdot 771 \mathrm{KgF} \approx 120,8 \text { Tons } \\
& \mathrm{P} 2+\mathrm{P} 3=241,6 \text { Tons }
\end{aligned}
$$

First stage cutting will require 323 Tons of force and second stage form inclined punch required 121 Tons of force so still applicable to process in 500 Tons stamping machine.

This combination type cutting process are divided into two stages, where first stage required 323 Tons of force and then follow by second process with shear method required 121 Tons of force. So this process will be able to worked in 500 Tons stamping machine

\section{CONCLUSIONS}

The design use combination type of flat and inclined cutting surface. The calculation shows that cutting force reduced significantly and this part can be process in 500 Tons machine compare with 1000Tons before. This combination may reduce the deformation of blank part rather than double incline (V-shaped). Inclined punch is choose for it ease of maintenance and manufacture. This design is theoretically acceptable and recommended to be manufactured.

\section{REFERENCES}

[1]. I. Suchy, Handbook of Die Design, 2nd Ed., Mc Graw-Hill, 2006

[2]. M. I. Khan, S. Haque, Manufacturing Science, PHI Learning Private Limited, New Delhi 2011.

[3]. T. Altan, A. E. Tekkaya, Sheet Metal Forming: Processes and Applications, ASM International, Ohio, 2012.

[4]. V. Boljanovic, Sheet Metal Forming Processes and Die Design, Industrial Press, New York, 2004.

[5]. Information

on

http://www.unipunch.com (02-07-2017)

[6]. Hong-Seok Choi, Byung-Min Kim, Dae-Cheol Ko, Effect of clearance and inclined angle on sheared edge and tool failure in trimming of DP980 sheet, Journal of Mechanical Science and Technology, June 2014, Vol. 28, Issue 6, pp 2319-2328

[7]. Vitoslav Bratus, Franc Kosel, Marko Kovac, Determination of optimal cutting edge geometry on a stamped orthotropic circular electrical steel sheet, Journal of Materials Precessing Technology 210 (2010), 396407

[8]. Yoshifumi Kumagai, Instruction Manual on Die Designing and Manufacturing Technology, Sokeizai Center, Tokyo, 1985. 